\begin{tabular}{|l|l|l||}
\hline \multicolumn{2}{|c|}{ PublisherInfo } \\
\hline \hline PublisherName & $:$ & BioMed Central \\
\hline \hline PublisherLocation & $:$ & London \\
\hline \hline PublisherImprintName & $:$ & BioMed Central \\
\hline \hline
\end{tabular}

\title{
Lucky Luke
}

\begin{tabular}{|l|l|l||}
\hline \multicolumn{2}{|c|}{ ArticleInfo } \\
\hline \hline ArticleID & $:$ & 4234 \\
\hline \hline ArticleDOI & $:$ & $10.1186 /$ gb-spotlight-20011024-01 \\
\hline \hline ArticleCitationID & $:$ & spotlight-20011024-01 \\
\hline \hline ArticleSequenceNumber & $:$ & 305 \\
\hline \hline ArticleCategory & $:$ & Research news \\
\hline ArticleFirstPage & $:$ & 1 \\
\hline \hline ArticleLastPage & $:$ & 2 \\
\hline \hline & & RegistrationDate : 2001-10-24 \\
ArticleHistory & $:$ & OnlineDate \\
\hline \hline ArticleCopyright & $:$ & BioMed Central Ltd2001 \\
\hline \hline ArticleGrants & $:$ & \\
\hline \hline ArticleContext & $:$ & 130592211 \\
\hline \hline
\end{tabular}




\section{Jonathan B Weitzman}

Email: jonathanweitzman@hotmail.com

It is believed that the evangelist Luke was born in Antioch in Syria and died in Thebes, Greece, around 150 C.E (AD). His body was transported to Constantinople (Turkey) in 338 C.E. and later transfered to Padua, Italy. In the Early Edition of the Proceedings of the National Academy of Sciences, Cristiano Vernesi and colleagues at the University of Ferrara, Italy, describe experiments to verify the origins of the Padua body (doi/10.1073/pnas.211540498). They followed strict guidelines to isolate mitochodrial DNA from one of Luke's teeth without contamination. Five amplicons were cloned and sequenced. After extensive statistical analysis the authors could not indisputably identify the geographical origins of the Padua body, but they could reject the hypothesis that the body came from a Greek. The data are compatible with a Syrian origin for Luke, but replacement of the body in Constantinople could not be ruled out.

\section{References}

1. Proceedings of the National Academy of Sciences, [http://www.pnas.org]

2. University of Ferrara, [http://www.unife.it]

3. Genetic characterization of the body attributed to the evangelist Luke, [http:/www.pnas.org/cgi/doi/ 10.1073/pnas.211540498]

4. Ancient DNA: do it right or not at all. 